\title{
Experimental Investigation on Short-term Properties of High-flowing Fine-grained Concrete Applying for Marine Structures
}

\author{
Trong-Phuoc Huynh ${ }^{1, *}$, Phuc-Huynh Bui ${ }^{2}$, Nguyen-Trong $\mathrm{Ho}^{3}$, Phuong-Trinh Bui ${ }^{4,5}$ \\ ${ }^{1}$ Department of Civil Engineering, College of Engineering Technology, Can Tho University, Campus II, 3/2 Street, Ninh Kieu District, \\ Can Tho City 900000, Vietnam \\ ${ }^{2}$ School of Graduate, Can Tho University, Campus II, 3/2 Street, Ninh Kieu District, Can Tho City 900000, Vietnam \\ ${ }^{3}$ Faculty of Civil Engineering, VSB-Technical University of Ostrava, Ludvika Podesta 1875/17, 70800 Ostrava-Poruba, Czech \\ Republic \\ ${ }^{4}$ Department of Construction Materials, Faculty of Civil Engineering, Ho Chi Minh City University of Technology (HCMUT), 268 Ly \\ Thuong Kiet Street, District 10, Ho Chi Minh City, Vietnam \\ ${ }^{5}$ Vietnam National University Ho Chi Minh City, Linh Trung Ward, Thu Duc District, Ho Chi Minh City, Vietnam
}

Received August 9, 2020; Revised September 23, 2020; Accepted October 19, 2020

\section{Cite This Paper in the following Citation Styles}

(a): [1] Trong-Phuoc Huynh, Phuc-Huynh Bui, Nguyen-Trong Ho, Phuong-Trinh Bui , "Experimental Investigation on Short-term Properties of High-flowing Fine-grained Concrete Applying for Marine Structures," Civil Engineering and Architecture, Vol. 8, No. 5, pp. 1047 - 1056, 2020. DOI: 10.13189/cea.2020.080531.

(b): Trong-Phuoc Huynh, Phuc-Huynh Bui, Nguyen-Trong Ho, Phuong-Trinh Bui (2020). Experimental Investigation on Short-term Properties of High-flowing Fine-grained Concrete Applying for Marine Structures. Civil Engineering and Architecture, 8(5), 1047 - 1056. DOI: 10.13189/cea.2020.080531.

Copyright $\bigcirc 2020$ by authors, all rights reserved. Authors agree that this article remains permanently open access under the terms of the Creative Commons Attribution License 4.0 International License

\begin{abstract}
The purpose of this study was to evaluate the engineering properties of the high-flowing fine-grained concrete (HFFC) developed using various components such as cement, slag, fly ash (FA), natural crushed sand, crushed stone, water, and superplasticizer (SP). Six HFFC mixture proportions were prepared in the laboratory, in which three mixtures got a variety of water-to-binder (w/b) ratio in the range of $0.32-0.42$ while the other three mixtures were setup from selected $\mathrm{w} / \mathrm{b}$ ratio of 0.37 and the substitution of Portland cement by slag at 0 (reference), 10, 20 , and $30 \%$ by mass of cement. Engineering properties of all HFFC specimens were evaluated through the tests of compressive strength, flexural strength, water absorption, porosity, drying shrinkage, and sulfate resistance. Additionally, the properties of fresh HFFC mixtures, including workability and unit weight, were measured. Test results showed that the cement replacement by slag significantly improved compressive and flexural strengths, and reduced water absorption and porosity of the HFFC samples when compared with the reference sample. Moreover, the use of slag to partially replace cement was found to enhance sulfate resistance and reduce drying
\end{abstract}

shrinkage of the HFFC samples. This study found that using slag could improve the engineering properties of HFFC for hydraulic structures.

Keywords Fine-Grained Concrete, Marine Structure, Compressive Strength, Flexural Strength, Water Absorption, Drying Shrinkage, Sulfate Resistance

\section{Introduction}

Concrete is one of the construction materials having a wide range of flexible applications in the world [1], especially applying for the marine environment with a high concentration of harmfully corrosive agents such as sulfate ions. However, there are some factors influencing the life cycle and durability of these structures, such as water/cement ratio, cement content, curing condition, aggregate quality, permeability, alkali-aggregate reaction, concrete quality, sulfate attack, etc. [2]. Therefore, various technical methods are suggested to investigate 
and produce new concrete generations to extend service life and enhance the durability of the concretes for the marine structures.

Several researchers have paid attention to the application of fine-grained concrete or high-flowing fine-grained concrete (HFFC), particularly in aggressive surroundings like the marine environment. Fine-grained concrete is also called sand concrete or fine aggregate concrete, in which coarse aggregate is replaced by the finer one [3]. Nevertheless, high cement content is one of the disadvantages of fine-grained concrete or HFFC. The cement content in the fine-grained concrete is approximately $30 \%$ higher than that in the traditional concrete. A use of superplasticizer (SP) and mineral additives (e.g. fly ash (FA), slag, and so on) supports not only to decrease the cement content but also to improve engineering properties including strength, workability, water resistance, shrinkage, porosity, and so on of fine-grained concretes [4]. Moreover, the positive role of nano-sized additives in the improvement of the properties of various types of concrete including fine-grained concretes was found in some previous studies [5], [6].

On the other hand, using industrial wastes such as FA and slag as secondary raw materials plays a crucial role in sustainable development [7]. Moreover, using industrial wastes in concrete technology not only lessens greenhouse gas emissions but also creates eco-friendly concrete and brings high economic efficiency [8]. The ground blast-furnace slag is used as an additive in the Portland slag cement manufacture in some countries where a huge amount of blast-furnace slag is released from steel production [9]. In fact, blast-furnace slag was used as a partial substitution for Portland cement from 1947 to 1952. From that, the concrete containing slag as binding material has been investigated and produced [10], [11]. Topçu and Ugurlu [12] stated that the compressive and flexural strengths were significantly improved by the addition of mineral filler to the concrete, particularly fine-grained concrete or HFFC. Similarly, Malhotra proved that the slag fineness, activity index, and slag-to-cement ratio in mixtures affected the strength of concrete containing slag [13]. The water absorption and porosity decrease with the increase in the workability of concrete [14].

This study focuses on using slag as the cement replacement in HFFC to develop engineering properties of such concrete to apply in marine structures. A number of laboratory tests for compressive and flexural strengths, water absorption, porosity, drying shrinkage, and sulfate resistance were carried out for this purpose.

\section{Experimental Details}

\subsection{Characteristics of Raw Materials}

This study prepared HFFC samples using cement, slag,
FA, crushed sand, natural crushed stone, water, and SP. A blended cement-slag-FA mixture played as binder material. The physical-chemical characteristics of these binder materials are shown in Table 1 . A high amount of both $\mathrm{CaO}$ and $\mathrm{SiO}_{2}$ could be found in cement, while major chemical compositions of slag were $\mathrm{SiO}_{2}, \mathrm{Al}_{2} \mathrm{O}_{3}$, and $\mathrm{CaO}$, and the major components of FA were $\mathrm{SiO}_{2}$ and $\mathrm{Al}_{2} \mathrm{O}_{3}$.

Table 1. Chemical Compositions of Original Materials

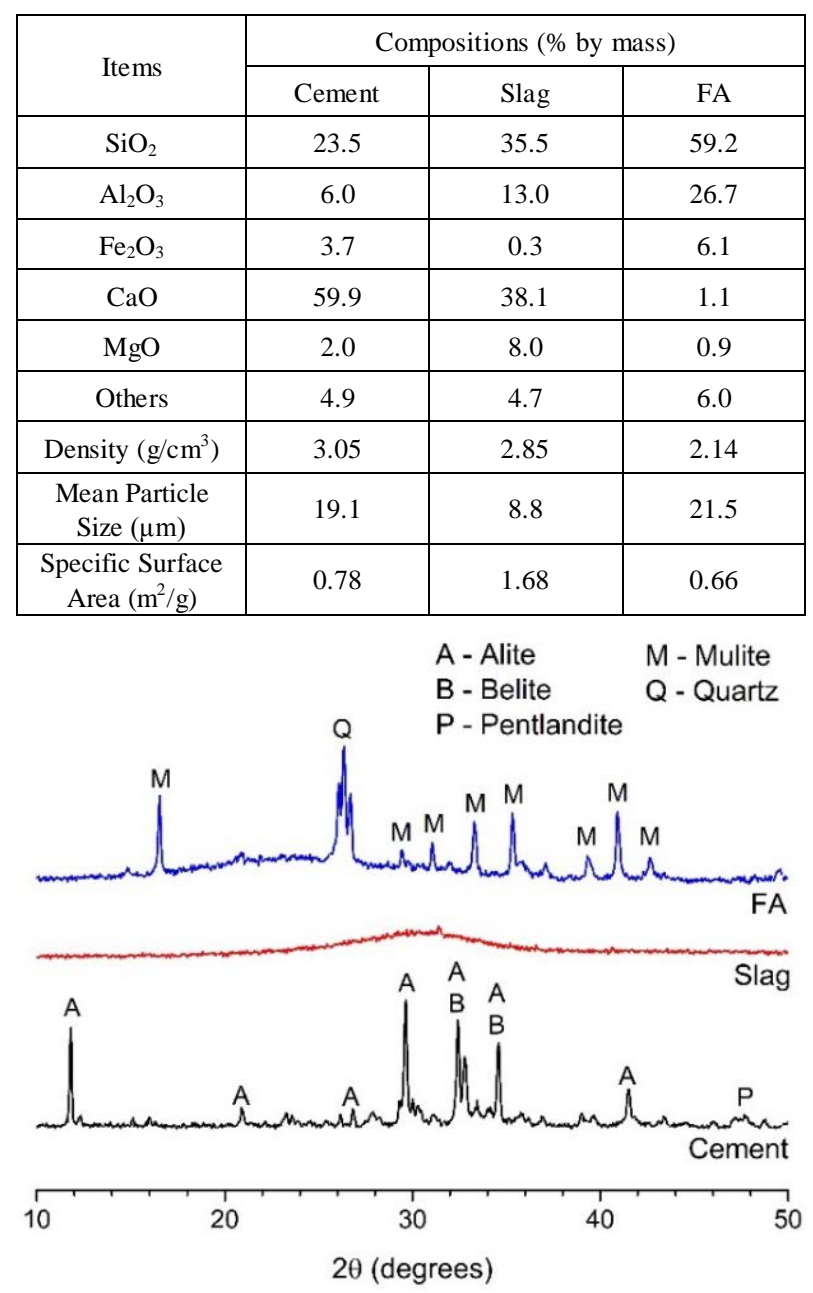

Figure 1. XRD Patterns of Original Materials

Figure 1 shows the mineralogical compositions of the cement, slag, and FA detected via X-ray diffraction (XRD) analysis. Alite and belite were mainly found in the cement while mulite and quartz existed in the FA. In addition, the non-crystallize phase was observed in the slag. Figure 2 shows the morphology of the cement, slag, and FA via scanning electron microscopic (SEM) analysis. The cement and slag had irregular shapes while the FA had a spherical shape with various particle sizes. The physical properties of crushed sand and natural crushed stone as fine and coarse aggregates in the HFFC mixture, respectively are shown in Table 2. Tap water was used as mixing water and SP sourced from China with a density of $1.15 \mathrm{~g} / \mathrm{cm}^{3}$ was used to obtain a high flowability of the HFFC mixtures. 


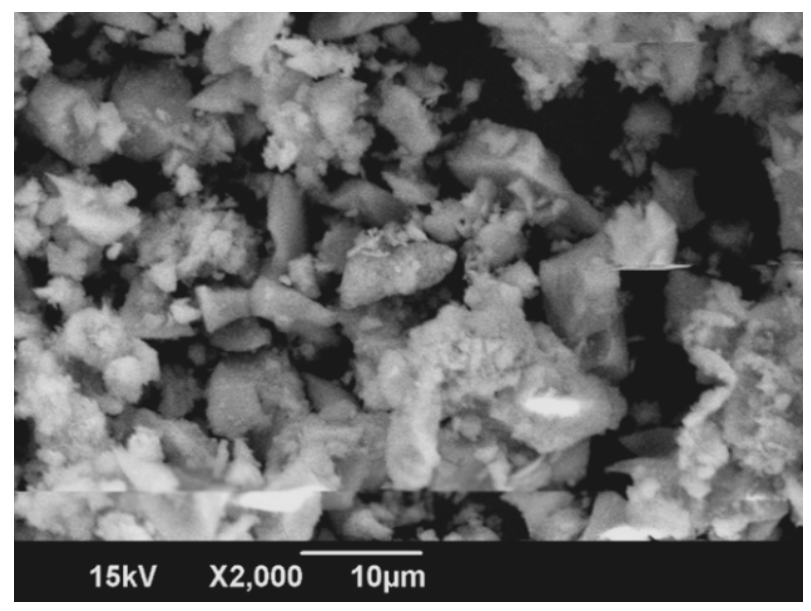

(a) Cement

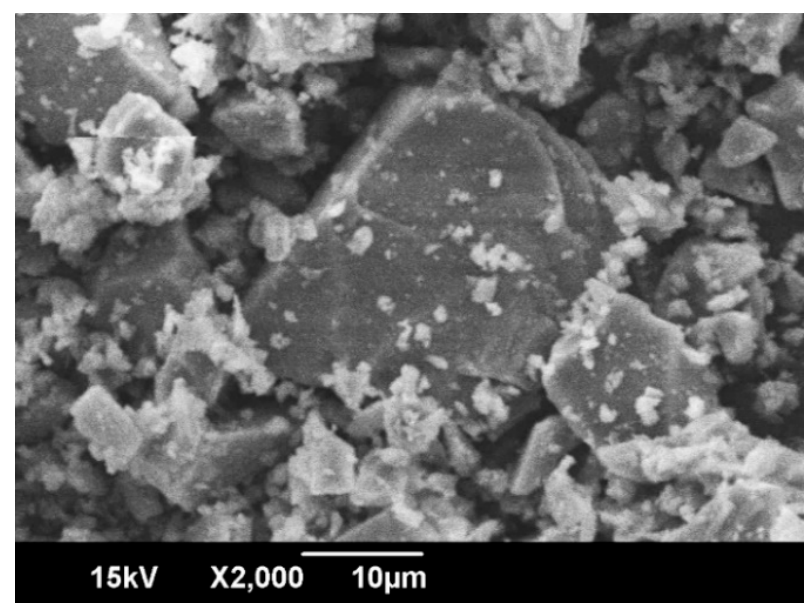

(b) Slag

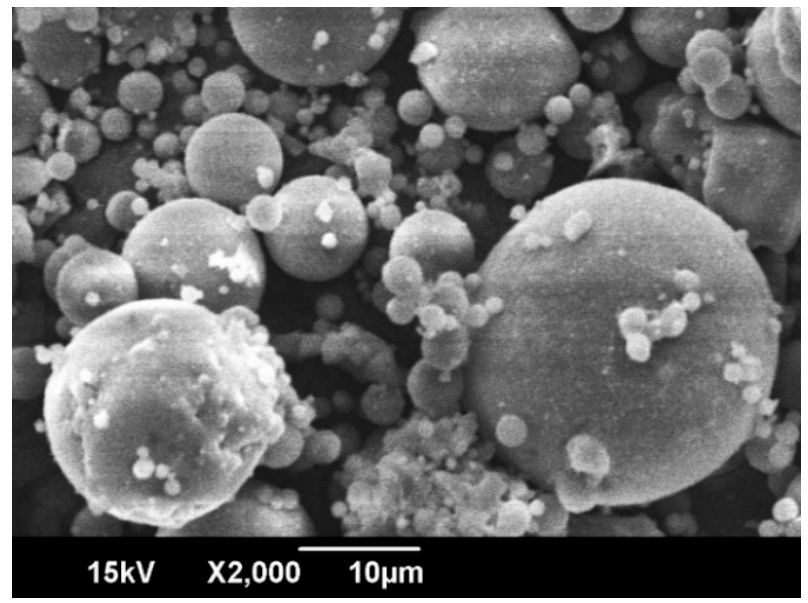

(c) FA

Figure 2. SEM Images of Original Materials

Table 2. Physical Properties of Aggregates

\begin{tabular}{|c|c|c|c|}
\hline Properties & $\begin{array}{c}\text { Density } \\
\left(\mathrm{kg} / \mathrm{m}^{3}\right)\end{array}$ & $\begin{array}{c}\text { Water } \\
\text { Absorption } \\
(\%)\end{array}$ & Remark \\
\hline $\begin{array}{c}\text { Crushed } \\
\text { sand }\end{array}$ & 2670 & 1.61 & $\begin{array}{c}\text { Fineness Modulus } \\
(\mathrm{FM})=3.69\end{array}$ \\
\hline $\begin{array}{c}\text { Crushed } \\
\text { stone }\end{array}$ & 2720 & 1.48 & $\begin{array}{c}\text { Maximum Diameter } \\
\left(\mathrm{D}_{\max }\right)=9.5 \mathrm{~mm}\end{array}$ \\
\hline
\end{tabular}

\subsection{Mixture Proportions}

Based on the pre-laboratory trials, six HFFC mixtures were designed for this study. In which, three mixtures were designed with various water-to-binder (w/b) ratios of 0.32 (W32S00), 0.37 (W37S00), and 0.42 (W42S00)) and the other three mixtures were designed with the same w/b ratio of 0.37 along with various slag contents as cement replacements. A constant aggregate-to-binder ratio (by weight) of 2.73 was applied for all of the HFFC mixtures. In this study, the controlled HFFC mixture denoted as W37S00 was designed using the densified mixture design algorithm (DMDA) with the procedures as described by Hwang and Hung [15]. The replacement ratios of cement by slag were 10, 20, and 30\% for the W37S10, W37S20, and W37S30 mixtures, respectively, while the amounts of FA and aggregates were kept constant for these mixtures. The dosage of SP was adjusted in order to control the designed slump values for all of the HFFC mixtures in a range of $25 \sim 30 \mathrm{~cm}$. The mixture proportions for all of the HFFC samples are given in Table 3.

Table 3. Mixture Proportions for the Preparation of HFFC Samples

\begin{tabular}{|c|c|c|c|c|c|c|c|}
\hline \multirow{2}{*}{ Mixtures } & \multicolumn{7}{|c|}{ Materials (unit: gram) } \\
\cline { 2 - 9 } & Cement & Slag & FA & Sand & Stone & Water & SP \\
\hline W32S00 & 3213 & 0 & 644 & 7027 & 3495 & 1234 & 26 \\
\hline W37S00 & 3213 & 0 & 644 & 7027 & 3495 & 1427 & 22 \\
\hline W42S00 & 3213 & 0 & 644 & 7027 & 3495 & 1620 & 18 \\
\hline W37S10 & 2892 & 321 & 644 & 7027 & 3495 & 1427 & 22 \\
\hline W37S20 & 2570 & 643 & 644 & 7027 & 3495 & 1427 & 21 \\
\hline W37S30 & 2249 & 964 & 644 & 7027 & 3495 & 1427 & 20 \\
\hline
\end{tabular}

\subsection{Sample Preparation and Test Methods}

A procedure of sample preparation was carried out as follows: (1) binder materials including cement, slag, and FA were dry-mixed in a laboratory mixer for one min; (2) two-thirds of mixing water was gradually added to the mixer followed by a part of SP; (3) all components were continuously mixed for two min to obtain a viscous paste; (4) aggregates were added to the paste followed by the rest part of water and SP; and (5) mixing was allowed to continue for two min in order to obtain a homogenous mixture. After mixing, the fresh properties of HFFC mixtures were immediately tested. Then, the HFFC samples were cast in various sizes for different test purposes as per the relevant standards. It is noted that all of the HFFC samples were de-molded one day after casting and then cured in lime-saturated water until the testing ages.

The fresh properties of the HFFC mixtures including slump, slump flow, and flow time were measured in accordance with TCVN 12209:2018 [16] while the fresh unit weight was measured in accordance with TCVN 3108:1993 [17]. The compressive strength test was 
performed at $1,3,7,14$, and 28 days according to TCVN 3118:1993 [18] using the cubic samples with dimensions of $10 \times 10 \times 10 \mathrm{~cm}$. Meanwhile, the flexural strength test was performed at 7 and 28 days according to TCVN 3119:1993 [19] using the prism concrete with dimensions of $15 \times 15 \times 55 \mathrm{~cm}$. The tests of water absorption and porosity of the HFFC samples were conducted at 28 days as per TCVN 3113:1993 [20] using the cubic samples with dimensions of $10 \times 10 \times 10 \mathrm{~cm}$. The tests of drying shrinkage and sulfate resistance of the HFFC samples were evaluated through the change in length of the prism concretes with dimensions of $7.5 \times 7.5 \times 28.5 \mathrm{~cm}$ that cured at room conditions and immersed in a $5 \% \mathrm{Na}_{2} \mathrm{SO}_{4}$ solution, respectively. The length change of the samples was monitored at 1, 3, 7, 14, and 28 days following the ASTM C157 [21]. The average value of repeated three measurements was reported for each test at each age.

\section{Test Results and Discussion}

\subsection{Fresh Properties}

Table 4 represents the fresh properties of all HFFC mixtures, including slump, slump flow, and flow time. For the W32S00, W37S00, and W42S00 mixtures, the mixture with a lower w/b ratio had a higher flow time than the others. Meanwhile, the mixture with a w/b ratio of 0.37 had a slump of $26 \mathrm{~cm}$, a slump flow of $62 \mathrm{~cm}$, and a flow time of $4 \mathrm{sec}$. Therefore, based on the experiment results, a w/b ratio of 0.37 was chosen as an optimum $w / b$ for the reference mixture.

It is clearly observed that the SP dosage in the mixtures containing slag (W37S20 and W37S30) slightly decreased when compared with the reference mixture containing no slag (W37S00). Additionally, the mixture with the replacing $10 \%$ cement by slag (W37S10) consumed the same SP amount as the reference mix (see Table 3). The SP dosage was found to be decreased as further increasing the slag replacement in the HFFC mixtures. The reduced SP dosage is due to the reduction in water demand of slag particles, which is attributable to the lower rate of slag hydration as compared to cement [22]. Moreover, the replacement of cement by slag also reduces the ettringite formation during the early stages of hydration, resulting in the improvement of the workability of the concrete mixture [23]. Thus, it can be concluded that slag required a low SP dosage to reach the designed slump flow with a constant mixing water amount.

The variation of unit weight in a fresh state of mixtures with the cement substitution by slag is also shown in Table 4. It is expected that the unit weight in the fresh state of HFFC with high slag replacement decreases with the increase in the slag replacement because the unit weight of slag is usually lower than that of cement [24]. In this study, the unit weight of HFFC mixtures with 10, 20, and $30 \%$ slag replacements was lower by $0.4,0.6$, and $1.2 \%$ than that of the reference sample with $0 \%$ slag replacement (W37S00).

Table 4. Properties of Fresh Concrete Mixtures

\begin{tabular}{|c|c|c|c|c|}
\hline Mixtures & $\begin{array}{c}\text { Slump } \\
(\mathrm{cm})\end{array}$ & $\begin{array}{c}\text { Slump } \\
\text { flow (cm) }\end{array}$ & $\begin{array}{c}\text { Flow time } \\
(\mathrm{sec})\end{array}$ & $\begin{array}{c}\text { Unit } \\
\text { weight } \\
\left(\mathrm{kg} / \mathrm{m}^{3}\right)\end{array}$ \\
\hline W32S00 & 25 & 59 & 10 & 2324 \\
\hline W37S00 & 26 & 62 & 4 & 2309 \\
\hline W42S00 & 28 & 58 & 3 & 2269 \\
\hline W37S10 & 25 & 59 & 5 & 2300 \\
\hline W37S20 & 26 & 63 & 6 & 2295 \\
\hline W37S30 & 26 & 61 & 5 & 2282 \\
\hline
\end{tabular}

\subsection{Compressive Strength}

The compressive strength of HFFC samples with various w/b ratios at the ages of $1,3,7,14$, and 28 days is illustrated in Figure 3. At 28-day age, the compressive strengths of samples with $\mathrm{w} / \mathrm{b}$ ratios of $0.32,0.37$, and 0.42 were $45.6,38.2$, and $35.3 \mathrm{MPa}$, respectively. It can be seen that an increase in $\mathrm{w} / \mathrm{b}$ ratio decreased the compressive strengths of HFFC samples by approximately $3-7 \%$ at all ages. The reduction of the $\mathrm{w} / \mathrm{b}$ ratio led to a decrease in microcracks between aggregate particles and cement paste, and porosity in the hardened concrete [25], [26]. Consequently, the compressive strength can be improved as the $\mathrm{w} / \mathrm{b}$ ratio decreases. This trend is in line with the previous study [27]. During the experimental work, it is found that the HFFC samples with a w/b ratio of 0.37 exhibited good performance in both fresh and hardened stages so this ratio was selected to evaluate the effect of various slag replacements on the properties of HFFC samples.

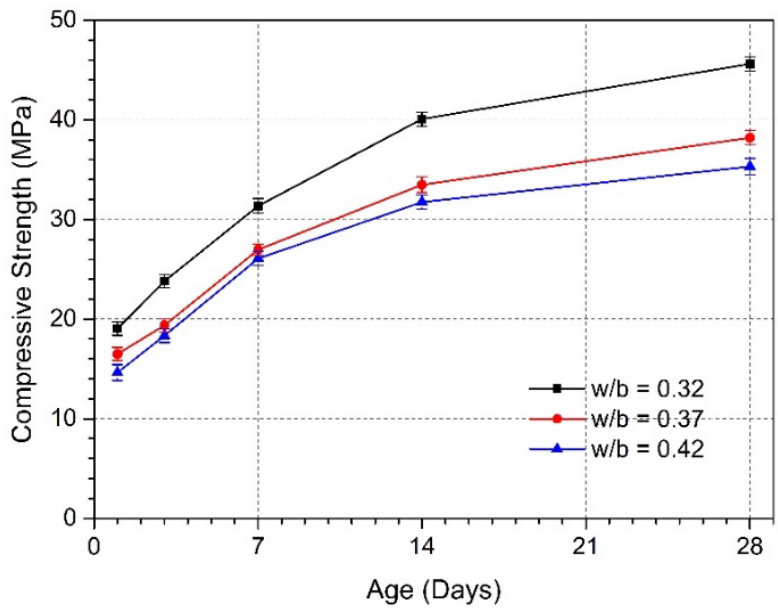

Figure 3. Compressive Strength of the HFFC Samples with Various w/b Ratios

On the other hand, the effect of slag replacements on the compressive strength of HFFC samples at the ages of 
1, 3, 7, 14, and 28 days is illustrated in Figure 4. Generally, the compressive strength of concrete, particularly HFFC specimens increases with normal curing time due to the cement hydration and the pozzolanic reaction of binder materials [28]. This tendency was also observed in this study. At 28-day age, the compressive strengths of HFFC samples with $0,10,20$, and $30 \%$ slag replacements corresponded to 38.2, 38.6, 40.2, and 43.6 MPa. Figure 4 also reveals that the compressive strength of samples with 10,20 , and $30 \%$ slag replacements increased by approximately 1, 5, and 15\%, respectively when compared with the reference sample with $0 \%$ slag replacement at the same age. Furthermore, it can be seen that the higher the slag replacement, the higher the compressive strength of HFFC specimens at 7-, 14-, and 28-day ages, but not at early ages (i.e., at 1- and 3-day ages). This is due to the cement replacement by slag which resulted in a decrease in the early-age strength but an increase in the later-age strength.

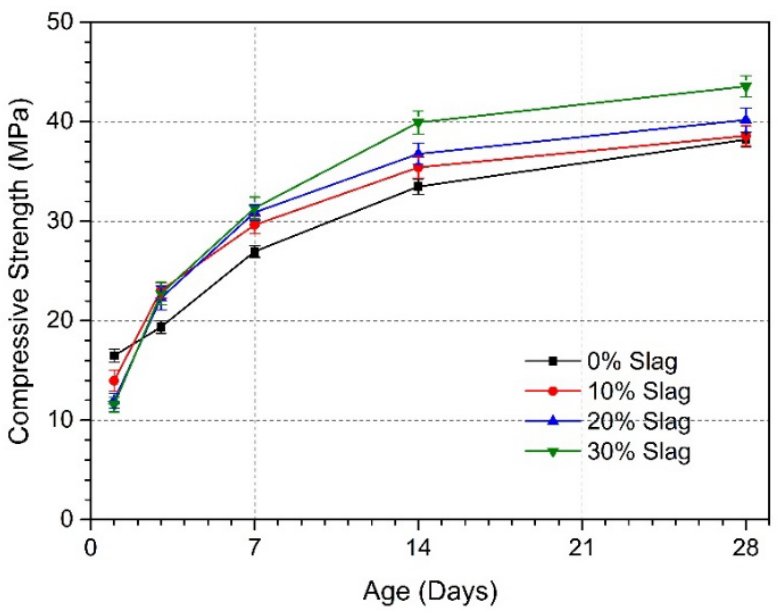

Figure 4. Compressive Strength of the HFFC Samples with and without Slag Replacements

\subsection{Flexural Strength}

The flexural strength is a vital engineering property of HFFC because it reflects the tension and deformation resistance of concrete. Marine structures often bear high water pressure and high deflection in a harsh seawater environment [29]. Thus, the higher the flexural strength value, the better the quality of concrete and versa vice. The flexural strength of three HFFC mixtures corresponding to various $\mathrm{w} / \mathrm{b}$ ratios at 7 - and 28-day ages is presented in Figure 5. At 28-day age, the flexural strengths of HFFC samples with w/b ratios of $0.32,0.37$, and 0.42 were 10.9 , 9.5 , and $8.2 \mathrm{MPa}$, respectively while these values at 07-day age were 10.0, 8.2, and 7.6 MPa. Similar to the compressive strength test, a reduction of the $w / b$ ratio generally increases the flexural strength of the concretes.

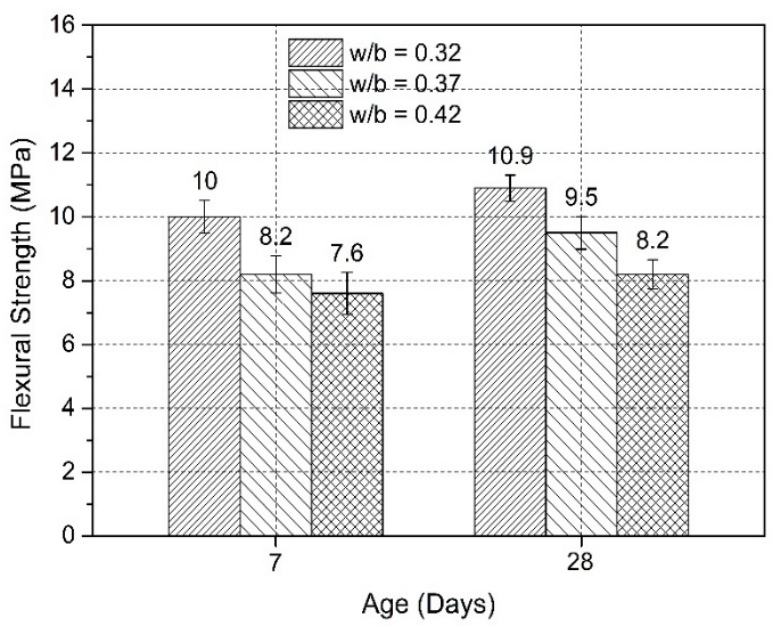

Figure 5. Flexural Strength of the HFFC Samples with Various w/b Ratios

The flexural strength of HFFC samples with and without slag replacements at 7- and 28-day ages is shown in Figure 6. Similar to the compressive strength, the flexural strength of HFFC increased with curing time and also increased with an increase in slag replacement. At 28-day age, the flexural strengths of HFFC samples with 0, 10, 20, and $30 \%$ cement replacements by slag were $9.5,9.7,9.9$, and 10.6 MPa, respectively. It can be seen that the flexural strength of the HFFC samples with 10, 20, and 30\% cement replacements by slag improved by 2,4 , and $12 \%$, respectively when compared with the reference concrete without slag. It is revealed that although slag is known as a pozzolanic material and plays a crucial role in the strength development, a low slag replacement (i.e., 10 or $20 \%$ replacement) did not help significantly enhance the flexural strength of the HFFC.

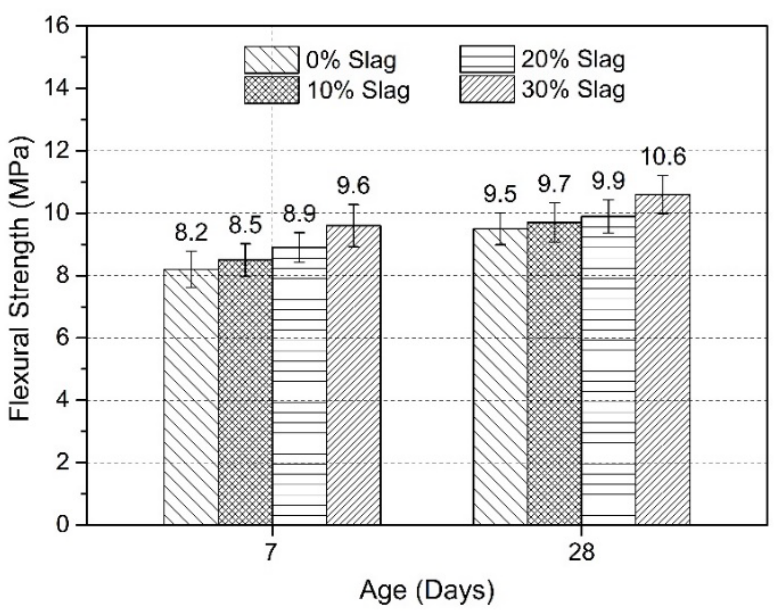

Figure 6. Flexural Strength of the HFFC Samples with and without Slag Replacements 


\subsection{Water Absorption and Porosity}

All marine structures always work in a seawater environment with many corrosive agents like sulfate ions and chloride salts or acids. In this condition, the resistance to chemical attack of hydraulic concrete is really important. Water absorption and porosity values at 28-day age reasonably reflecting the corrosion resistance of HFFC with various w/b ratios are shown in Figure 7. The water absorption values increased from 8.3, 8.9, and $10.6 \%$ corresponding to the HFFC mixtures of W32S00, W37S00, and W42S00, respectively. This is because the water absorption of concrete was greatly affected by the $\mathrm{w} / \mathrm{b}$ ratio. In general, the higher the $\mathrm{w} / \mathrm{b}$ ratio, the higher the pores generated from the free water evaporation in concrete [26]. In fact, the porosity of the HFFC increased as an increasing $\mathrm{w} / \mathrm{b}$ ratio and achieved 3.6, 3.9, and $4.8 \%$ corresponding to the HFFC mixtures of W32S00, W37S00, and W42S00, respectively.

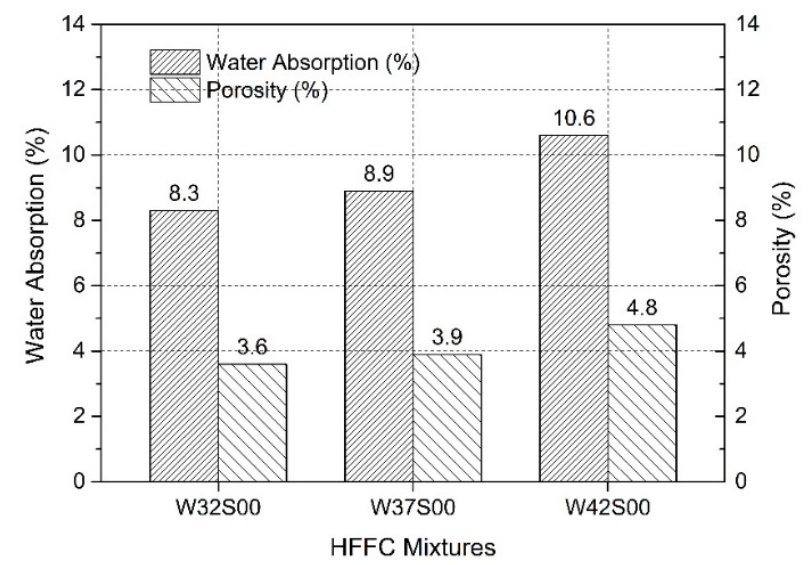

Figure 7. Water Absorption and Porosity of the HFFC Samples with Various w/b Ratios

The water absorption and porosity of the HFFC samples with and without slag replacements at 28-day age are shown in Figure 8. According to Figures 7 and 8, the water absorption value of the reference mixture (W37S00) was $8.9 \%$. When the cement replacement by slag at levels of 10,20 , and $30 \%$, the water absorption values of the HFFC samples were 8.6, 7.7, and 6.3\%, respectively. It is clear that the water absorption of mixtures tended to decrease when the replacement ratio of ordinary Portland cement by slag increased. This result is appropriate with a previous study of Topçu and Ünverdi [30]. The main reason for the decrease in water absorption is due to the less porous structure of concrete, which is partially filled by slag. The fine particles of slag could block some continuous pore network in the matrix, leading to the reduction in water absorption of concrete [22]. In addition, the pozzolanic reaction of slag generated secondary calcium-silicate-hydrate (C-S-H) gel, which is attributable to the reduction in capillary and gel porosity and consequently reducing water absorption rate of the concrete [31].

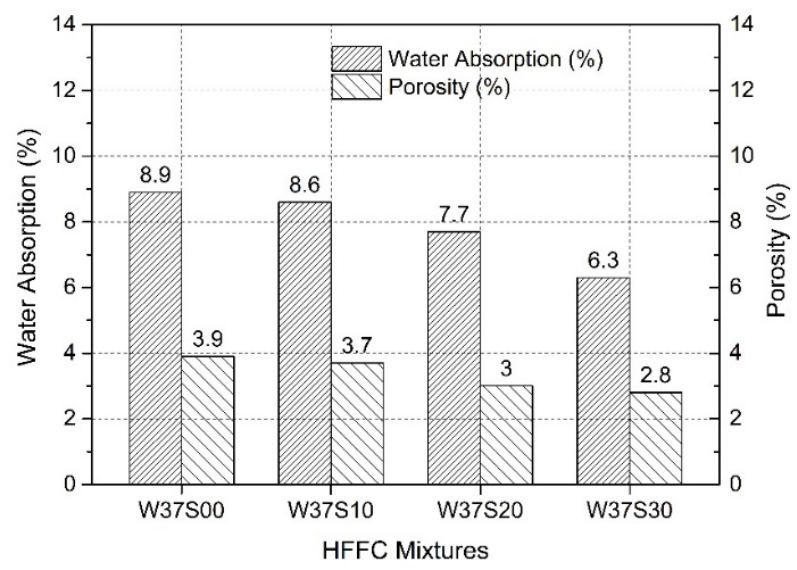

Figure 8. Water Absorption and Porosity of the HFFC Samples with and without Slag Replacements

Similar to the water absorption, the porosity of the HFFC specimens decreased as the slag replacement increased (see Figure 8). The porosity values were 3.9, 3.7, 3.0 , and $2.8 \%$ corresponding to the HFFC samples with 0 , 10,20 , and $30 \%$ slag, respectively. The water absorption was increased proportionally with the porosity (Figure 9). This correlation is presented by the linear equation of $y=$ $1.895 x+1.488\left(\mathrm{R}^{2}=0.93\right)$. In which, $x$ and $y$ represent for porosity and water absorption rate, respectively. It is apparent that the porosity had a direct influence on the strength of concrete [27] as a reduction of the concrete strength is caused by higher porosity as mentioned.

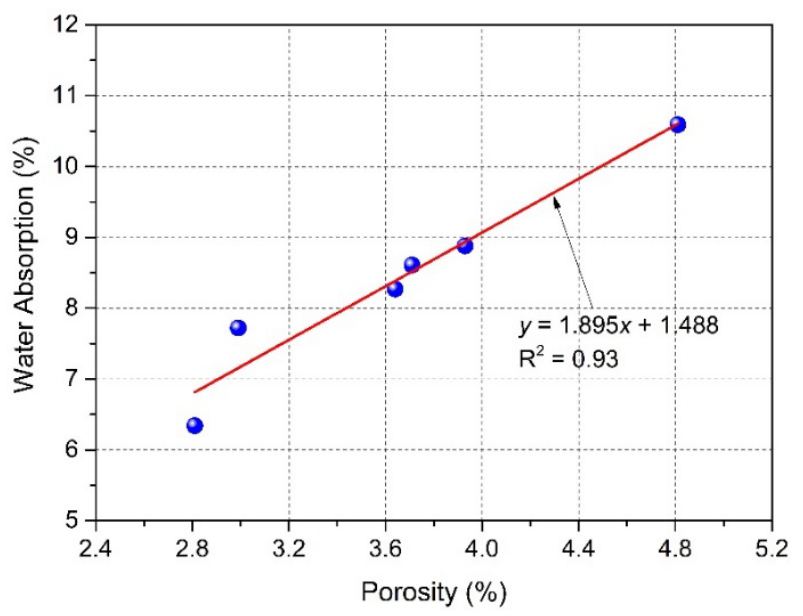

Figure 9. The Relationship between Water Absorption and Porosity of the HFFC Samples

\subsection{Drying Shrinkage}

Drying shrinkage of HFFC samples with various w/b ratios is given in Figure 10. The test was evaluated through the length change of the HFFC mixtures with various $w / b$ ratio cured at room conditions from the age of 1 to 28 days. It can be seen that drying shrinkage decreased by approximately $15 \%$ with the reduction of $w / b$ and drying 
shrinkage increased by about 20\% during the curing time. During the drying process, water loss in the samples caused drying shrinkage, and the increase in the $\mathrm{w} / \mathrm{b}$ ratio can increase the volume of capillary pore and decreased the water loss barrier [26]. As a result, the increase in w/b and curing time can lead to an increase in the drying shrinkage.

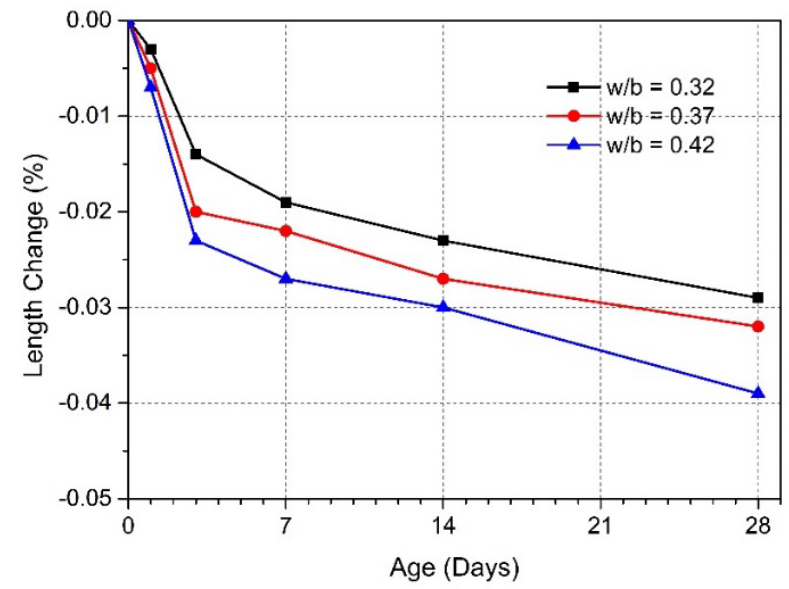

Figure 10. Change in Length of the HFFC Samples with Various w/b Ratios

Figure 11 shows the length change of the HFFC mixtures with various slag replacements cured in lime-saturated water until 28-day age. At 28-day age, the drying shrinkage values achieved $0.032,0.030,0.025$, and $0.020 \%$ corresponding to the HFFC specimens with 0,10 , 20 , and $30 \%$ slag, respectively. From these experimental results, the drying shrinkage of samples reduced with increasing slag replacement. At an early age (i.e., at 1 day), the length change suddenly tended to increase when increasing the slag replacement and this tendency was contrary to the HFFC mixtures at later ages. Additionally, the results of this study also indicated that a partial replacement of Portland cement by slag reduced drying shrinkage when compared with the reference mixture containing no slag and it is appropriate with results reported in previous research [32].

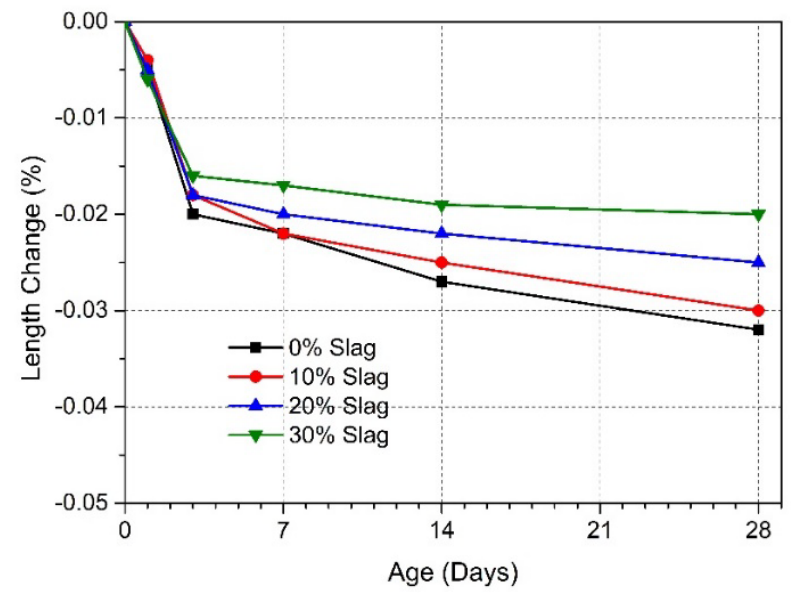

Figure 11. Change in Length of the HFFC Samples with and without Slag Replacements

\subsection{Sulfate Resistance}

Sulfate attack is one of the most important problems concerning the durability of hydraulic concrete structures, especially in the sulfate environment like seawater. The influence of the $\mathrm{w} / \mathrm{b}$ ratio on the sulfate attack resistance of test samples was therefore analyzed and is shown in Figure 12. In this study, the length change of mixtures immersed under $5 \% \mathrm{Na}_{2} \mathrm{SO}_{4}$ solution was used to evaluate the resistant ability to sulfate attack. The change of length was at $0.019,0.023$, and $0.027 \%$ corresponding to the HFFC mixtures with the $w / b$ ratios of $0.32,0.37$, and 0.42 , respectively. It is apparent that increasing the $\mathrm{w} / \mathrm{b}$ ratio of HFFC specimens increased their length change, which is primarily due to the increment of porosity and shrinkage of the concrete [25], [26].

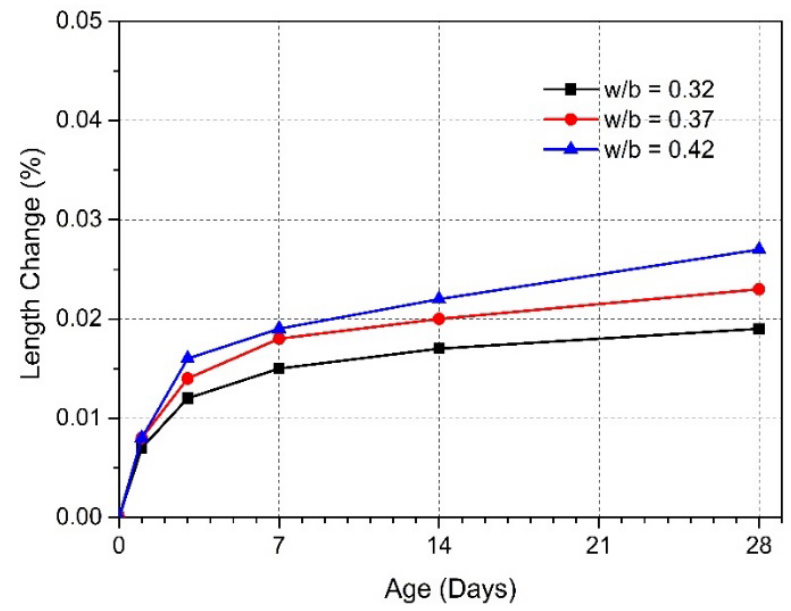

Figure 12. Change in Length of the $5 \% \mathrm{Na}_{2} \mathrm{SO}_{4}$-Immersed HFFC Samples with Various w/b Ratios

The influence of slag replacement on the sulfate attack resistance of test samples was also analyzed and is shown in Figure 13. At 28-day age, the length change values reached $0.023,0.021,0.019$, and $0.016 \%$ corresponding to the HFFC with $0,10,20$, and $30 \%$ slag replacements. According to this research, it is concluded that the length change of HFFC samples reduced when increasing the replacement ratio of Portland cement by slag. This finding is also in line with the results from previous studies [33], [34]. Moreover, due to its high fineness, slag is a common material that is widely used to substitute for ordinary Portland cement to improve the engineering properties of concrete structures in the marine environment. With very high fineness, the addition of slag into concrete can effectively fill the pores of the concrete to reduce the permeability of concrete [30] and make concrete more impermeable. Additionally, Islam et al. [34] stated that slag would react with the cement hydration products to form secondary C-S-H gel. This also takes account of making impermeable concrete to restrict the penetration of sulfate ions from seawater inside the HFFC, consequently reducing the risk of sulfate-induced deterioration. 


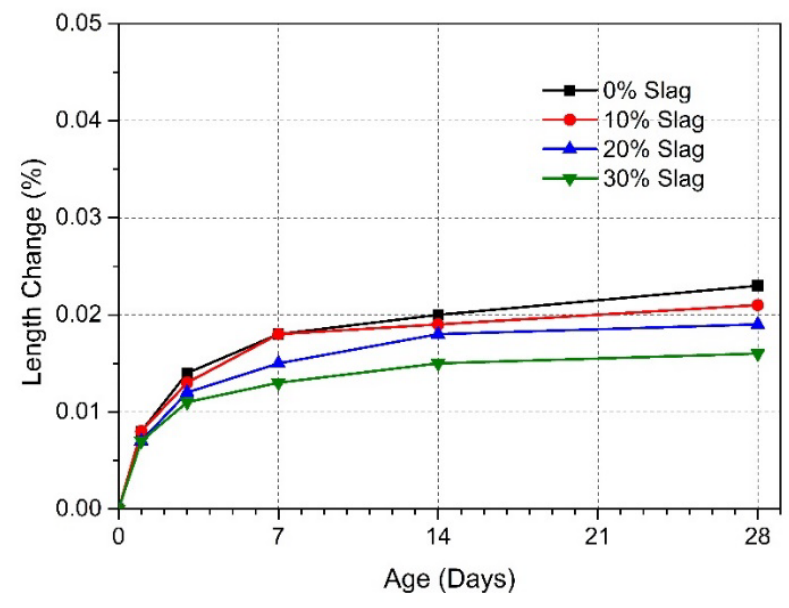

Figure 13. Change in Length of the $5 \% \mathrm{Na}_{2} \mathrm{SO}_{4}$-Immersed HFFC Samples with and without Slag Replacements

\section{Conclusions}

The effect of a partial replacement of Portland cement by slag on the engineering properties of high-flowing fine-grained concrete (HFFC) applying in the marine environment was investigated in this study. Three water-to-binder ratios used were $0.32,0.37$, and 0.42 . Three replacement ratios of Portland cement by slag were 10,20 , and $30 \%$ by mass was prepared for the HFFC with a selected $\mathrm{w} / \mathrm{b}$ ratio of 0.37 . Based on the experimental results, the following conclusions can be drawn:

First, as increasing the substitution of cement by slag, the unit weight of fresh HFFC mixtures was reduced because the unit weight of slag was lower than that of cement.

Second, when increasing the $\mathrm{w} / \mathrm{b}$ ratio, the compressive strength of the HFFC specimens intended to reduce by 3-7\% at all ages of the concretes. Meanwhile, the compressive strength improved by 1,5 , and $15 \%$ corresponding to the 28-day-old HFFC specimens with 10, 20, and $30 \%$ slag replacements.

Third, a reduction of the $\mathrm{w} / \mathrm{b}$ ratio generally increased the flexural strength of the HFFC. When the substitution of cement by slag at 10,20 , and $30 \%$ by mass, the flexural strength of the HFFC improved by 2, 4, and $12 \%$, respectively.

Fourth, the water absorption of the HFFC specimens was significantly influenced by the $\mathrm{w} / \mathrm{b}$ ratio. The water absorption had a positive relationship with the porosity of the HFFC. Moreover, slag plays a crucial role in decreasing water absorption and porosity of HFFC samples, resulting in improving the strength and durability of such concrete applying for marine structures.

Fifth, in the w/b ratio range of $0.32-0.42$, the increase in $\mathrm{w} / \mathrm{b}$ ratio increased the drying shrinkage of the HFFC by approximately $15 \%$ whereas curing time led to increase drying shrinkage about $20 \%$. However, at a given $\mathrm{w} / \mathrm{b}$ ratio of 0.37 , drying shrinkage tended to reduce corresponding to the increase in cement replacement by slag.

Sixth, for the resistant ability to sulfate attack, increasing the $w / b$ ratio intended to increase the length change of the HFFC specimens while the slag replacement reduced the length change of the HFFC specimens containing slag.

Seventh, the HFFC developed in this study can be widely applied in the real construction industry not only for marine structures but also for other construction activities with considering the requirements for each specific application.

\section{Acknowledgments}

The authors would like to express the special thanks to Mr. Van-Hien Pham, Mr. Trong-Binh Pham, and Mr. Tri-Khang Lam at Can Tho University, Vietnam for valuable assistance during the experimental works.

\section{REFERENCES}

[1] M.F. Nuruddin, S. Demie, N. Shafiq. Effect of mix composition on workability and compressive strength of self-compacting geopolymer concrete, Canadian Journal of Civil Engineering, Vol. 38, No. 11, 1196-1203, 2011. https://doi.org/10.1139/111-077

[2] The Constructor - Civil Engineering Home for Civil Engineers, 15 factors affecting durability of concrete. Assessed on August 8, 2020.

https://theconstructor.org/concrete/factors-affecting-durabili ty-concrete/1115/

[3] T.H. Le, T.S. Nguyen, H.M. Ludwig. A study on high performance fine-grained concrete containing rice husk ash, International Journal of Concrete Structures and Materials, Vol. 8, 301-307, 2014.

https://doi.org/10.1007/s40069-014-0078-z

[4] N.P. Lukuttsova, G.N. Soboleva, S.N. Golovin, E.V. Chivikova, E.V. Ogloblina. Fine-grained high-strength concrete, Materials Science Forum, Vol. 945, 131-135, 2019. https://doi.org/10.4028/www.scientific.net/MSF.945.131

[5] N.P. Lukuttsova, E.G. Karpikov, I.G. Luginina, A.A. Pykin, A.G. Ustinov, I.N. Pinchukova. High-performance fine concrete modified with nano-dispersion additive, International Journal of Applied Engineering Research, Vol. 22, 16725-16731, 2014.

[6] N.P. Lukuttsova, S.N. Golovin. Aggregative stability of aqueous suspensions of halloysite nanotubes, Building Materials, Vol. 1-2, 4-10, 2018.

https://doi.org/10.31659/0585-430X-2018-756-1-2-4-10

[7] I. Yüksel, Ö. Özkan, T. Bilir. Use of granulated blast-furnace slag in concrete as fine aggregate, ACI Materials Journal, Vol. 103, No. 3, 203-208, 2006.

https://www.concrete.org/publications/internationalconcrete abstractsportal/m/details/id/15854

[8] K. Mehta. Advancements in concrete technology, Concrete 
International, Vol. 21, No. 6, 69-76, 1999.

https://www.concrete.org/publications/internationalconcrete abstractsportal $/ \mathrm{m} /$ details/id/256

[9] ACI Committee 233. Ground granulated blast-furnace slag as a cementitious grout in concrete (ACI 233R-95), American Concrete Institute, Farmington Hills, Mich., 1995.

[10] N. Stutterheim. Portland blast furnace cements - A case for separate grinding of slag, $5^{\text {th }}$ International Symposium on the Chemistry of Cement Part IV, Cement Association of Japan, Tokyo, 1969, pp. 270-274.

[11] R.C. Mielenz. Mineral admixtures - History and background, Concrete International, Vol. 5, No. 8, 34-42, 1983. https://www.concrete.org/publications/internationalconcrete abstractsportal/m/details/id/9176

[12] I.B. Topçu, A. Ugurlu. Effect of the use of the mineral filler on the properties of concrete, Cement and Concrete Research, Vol. 33, No. 7, 1071-1075, 2003. https://doi.org/10.1016/S0008-8846(03)00015-2

[13] V.M. Malhotra. Properties of fresh and hardened concrete incorporating ground granulated blast furnace slag, supplementary cementing materials for concrete, V. M. Malhotra, ed., Canadian Government Publishing Centre, Ottawa, Canada, 1987, pp. 291-331.

[14] A.M. Neville. Properties of concrete, Fourth Edition, Longman, 1999, pp. 844.

https://books.google.com.vn/books/about/Properties_of_Co ncrete.html?id=mKEeAQAAIAAJ\&redir_esc $=y$

[15] C.L. Hwang, M.F. Hung. Durability design and performance of self-consolidating lightweight concrete, Construction and Building Material, Vol. 19, 619- 626, 2005.

https://doi.org/10.1016/j.conbuildmat.2005.01.003

[16] TCVN 12209:2018. Self-compacting concrete Specification and test method, Ministry of Science and Technology, Vietnam, 2018. https://vanbanphapluat.co/tcvn-12209-2018-be-tong-tu-lenyeu-cau-ky-thuat-va-phuong-phap-thu

[17] TCVN 3108:1993. Heavyweight concrete compounds Method for determination of density, Ministry of Science and Technology, Vietnam, 1993.

https://vanbanphapluat.co/tcvn-3108-1993-hon-hop-be-tong -nang-phuong-phap-xac-dinh-khoi-luong-the-tich

[18] TCVN 3118:1993. Heavyweight concrete - Method for determination of compressive strength, Ministry of Science and Technology, Vietnam, 1993.

https://vanbanphapluat.co/tcvn-3118-1993-be-tong-nang-ph uong-phap-xac-dinh-cuong-do-nen

[19] TCVN 3119:1993. Heavyweight concrete - Method for determination of flexural tensile strength, Ministry of Science and Technology, Vietnam, 1993. https://vanbanphapluat.co/tcvn-3119-1993-be-tong-nang-ph uong-phap-xac-dinh-cuong-do-keo-khi-uon

[20] TCVN 3113:1993. Heavyweight concrete - Method for determination of water absorption, Ministry of Science and Technology, Vietnam, 1993.

https:/vanbanphapluat.co/tcvn-3113-1993-be-tong-nang-ph uong-phap-xac-dinh-do-hut-nuoc

[21] ASTM C157. Standard test method for length change of hardened hydraulic-cement mortar and concrete, American Society of Testing Materials, 2017.

https://www.astm.org/Standards/C157

[22] S. Gupta. Effect of content and fineness of slag as high volume cement replacement on strength and durability of ultra-high performance mortar, Journal of Building Materials and Structures, Vol. 3, 43-54, 2016. https://doi.org/10.5281/ZENODO.242626

[23] B. Samet, M. Chaabouni. Characterization of the Tunisian blast-furnace slag and its application in the formulation of a cement, Cement and Concrete Research, Vol. 34, No. 7, 1153-1159, 2004.

https://doi.org/10.1016/j.cemconres.2003.12.021

[24] İ.B. Topçu, M. Canbaz. Alkali-silica reaction of alkali activated slag mortars, Seminary of structure mechanics, METU-ESOGU, Eskişehir, Turkey, 2008, pp. 117-124.

[25] J. Bisschop, P. Lura, J.G.M. van Mier. Shrinkage microcracking in cement-based materials with low water-cement ratio, Concrete Science and Engineering, Vol. 3, 151-156, 2001.

https://www.rilem.net/publication/publication/28?id_papier $=1959$

[26] Y.Y. Kim, K.M. Lee, J.W. Bang, S.J. Kwon. Effect of w/c ratio on durability and porosity in cement mortar with constant cement amount, Advances in Materials Science and Engineering, Vol. 2014, Paper No. 273460, 2014.

https://doi.org/10.1155/2014/273460

[27] A.M. Neville. Properties of concrete, $5^{\text {th }}$ Edition, Prentice Hall, 2013.

https://www.amazon.com/Properties-Concrete-5th-M-Nevil le/dp/0273755803

[28] Y. Feng, Q. Zhang, Q. Chen, D. Wang, H. Guo, L. Liu, Q, Yang. Hydration and strength development in blended cement with ultrafine granulated copper slag, Plos One, Vol. 14, No. 4, Paper No. e0215677, 2019. https://doi.org/10.1371/journal.pone.0215677

[29] S.S. Ho. Stainless steel capacitive pressure sensors for harsh environment application, The doctor of philosophy dissertation at Department of Materials Science and Engineering, Case Western Reserve University, USA, 2012. https://etd.ohiolink.edu/!etd.send_file?accession=case13159 60232\&disposition=inline

[30] İ.B. Topçu, A. Ünverdi. Properties of high content ground granulated blast furnace slag concrete. In: Firat S., Kinuthia J., Abu-Tair A. (eds) Proceedings of $3^{\text {rd }}$ International Sustainable Buildings Symposium (ISBS 2017), 2018, pp.114-126.

https://doi.org/10.1007/978-3-319-63709-9_9

[31] A. Elahi, P. Basheer, S. Nanukuttan, Q. Khan. Mechanical and durability properties of high performance concretes containing supplementary cementitious materials, Construction and Building Materials, Vol. 24, No. 3, 292-299, 2010.

https://doi.org/10.1016/j.conbuildmat.2009.08.045

[32] J. Yuan, W. Lindquist, D. Darwin, J. Browning. Effect of slag cement on drying shrinkage of concrete, ACI Materials Journal, Vol. 112, No. 2, 267-276, 2015. https://www.concrete.org/publications/internationalconcrete abstractsportal/m/details/id/51687129 
[33] G.J. Osborne. Durability of Portland blast-furnace slag cement concrete, Cement and Concrete Composites, Vol. 21, 11-21, 1999. https://doi.org/10.1016/S0958-9465(98)00032-8

[34] Md. M. Islam, Md. S. Islam, B.C. Mondal, M.R. Islam.
Strength behavior of concrete using slag with cement in sea water environment, Journal of Civil Engineering (IEB), Vol. 38, No. 2, 129-140, 2010.

https://www.researchgate.net/publication/265989952_Strength_ behavior_of_concrete_using_slag_with_cement_in_sea_water_ environment 